\title{
The SDGs and the Empowerment of Bangladeshi Women
}

\author{
Naomi Hossain
}

\subsection{INTRODUCTION}

Changes in the lives of Bangladeshi women and girls have been held up as evidence that aid, political commitment, and partnerships with civil society can transform gender relations and empower women in the development process. The evidence of this transformation is visible. Bangladeshi women occupy a broader range of roles in their society - as factory workers, teachers and students, entrepreneurs, and explorers that have conquered Mount Everest, officials, prime ministers, models, journalists, protestors, international peacekeepers, migrant workers, police officers, as well as mothers, daughters, and wives - than could have been imagined at the country's birth, a mere couple of generations ago. The social transformation this new visibility implies is real. As the world gears up to meeting the Sustainable Development Goals (SDGs), it is worth understanding what Bangladesh has achieved, and how.

Bangladesh made surprisingly rapid and simultaneous progress on poverty and gender equality in the 1990s and 2000s. Women were included in the national development project in ways that recognised how their vulnerability and lack of power bred poverty and deepened gender inequalities; programmes and policies were designed to reach them in ways that amended, without radically transforming, gender relations. Lessons from Bangladesh's past development successes have already been widely shared in a growing body of literature $^{1}$; this chapter looks forward, reflecting on the conditions under

N. Hossain $(\varangle)$

Accountability Research Center, American University, Washington, DC, USA

e-mail: hossain@american.edu

(C) The Author(s) 2021 
which Bangladesh made its gains on gender equality and women's empowerment during the Millennium Development Goals (MDGs) (1990-2015), and discusses how such inclusive policies became possible. It then builds on that analysis to assess the prospects for the achievement of the SDGs, with their stronger emphasis on inclusion, equality, and "leaving no one behind".

It should be noted that Bangladesh is no paradise of gender equality, and that women and girls face a broad range of discrimination and disadvantage because of their gender and its intersections with poverty and minority status. Violence against women and early marriage remain key concerns, and women and girls experience routine violations of their political, civic, and economic rights. Bangladesh faces significant challenges in meeting its SDG commitments, and these are being exacerbated by an apparent rise in the influence of political Islam (Nazneen 2018). Yet Bangladesh stands out in respect of women's empowerment and gender equality, in that it made relatively rapid gains from a low starting point-gains that could not be predicted from the country's social and gender relations at the time of its independence in 1971. At that time, it was a country with extensive poverty and a predominantly agrarian socio-economic structure, characteristics that do not usually facilitate rapid progress on gender equality (Mason and King 2001). It remains a Muslim-majority society situated within what Deniz Kandiyoti termed the belt of "classic patriarchy" (Kandiyoti 1988), which again are societal features believed to deter gender equality policies and programmes. Bangladesh is known to have performed "surprisingly" well in terms of reaching the most disadvantaged with health, education, and social protection services, and it is regarded as a "positive deviant" for having done so despite its overall low level of development and public spending (Asadullah et al. 2014; Chowdhury et al. 2013; Hossain 2017). Its performance on gender equality and women's empowerment is similarly surprising and merits explanation (Hossain 2018; Nazneen 2019).

The main argument of this chapter is that the relatively rapid improvements in the lives of, and opportunities for, Bangladeshi women owe in particular to comparatively strong elite commitment and increasing state capacity to reach and include women in the development process. As will be explained in the following, this elite commitment in turn grew out of a series of crises that highlighted the inadequate protections of patriarchal gender relations for many women. It led to their incorporation within the political settlement as citizens with rights as well as - through their reproductive roles—prime objects of, and vehicles for, governmental social policy.

In the aftermath of a brutal period of political violence and instability, a reasonably strong and enduring informal consensus emerged among the political, civil, military, economic, and social elites about the need to reach Bangladeshi women as integral to the larger project of national development (Hossain 2005, 2018). The elite were themselves a homogenous and closeknit group, and the crises of the early 1970s signalled a threat to the survival of the elite itself, and potentially even to national sovereignty. Forged in the 
shadow of economic disaster, famine, and assassination, the consensus included building better relationships with aid donors and accepting their conditionalities and priorities-for instance, around fertility control-where these were in line with the larger goal of development (Hossain 2017). The urgency of the need for economic stability and growth and for reaching the poor and vulnerable population licensed a range of innovative and experimental programmes and policies in Bangladesh, with creative partnerships and space for all manner of actors and ideas (Hossain 2017). From the 1970s to the 2000s, Bangladesh was a major recipient of foreign aid, including food aid. With economic growth, this relative dependence has declined significantly: Official development assistance comprised almost 6 per cent of annual gross domestic product in the 1980s, a figure that had dropped to around 1.5 per cent by the $2010 \mathrm{~s}$ (Khatun 2018). At some point in the early 2020s, Bangladesh is expected to graduate from the category of "least-developed country" (LDC), the first large country to do so. It is widely seen as an example of effective aid, and a central focus on women was part of that (Abed 2013; Asadullah et al. 2014; Chowdhury et al. 2013).

From the 1990s onwards, this developmental focus on women could be seen in the rising number of girls enrolled in schools, women receiving health care and other services, and women in paid work in export factories or selfemployment through micro-credit schemes (Kabeer and Hossain 2004). Laws, policies, and programmes to protect women and children against violence and to protect the most vulnerable from hunger and poverty were passed and implemented. Women played a growing role in politics through quotas and reservations, and they were employed in increasing numbers by the state, including as teachers, health workers, administrators, and the police (Nazneen and Sultan 2010; Nazneen et al. 2011).

But if elite commitment and state capacity were necessary elements of Bangladesh's unexpected success with women's empowerment and the MDGs, as is discussed further below, are they present and aligned in support of the SDGs? Can Bangladesh sustain its remarkable progress as it graduates out of the official LDC status of the United Nations (UN) in the early 2020s, with its implications for preferential trade and aid arrangements? How successfully will the country negotiate between a growing Islamist backlash against women's rights and the vocal demands of the country's robust women's movement (Nazneen 2018)? To answer these questions, the chapter first sets out the scale and nature of Bangladesh's success with gender equality, drawing attention to its MDG attainments and to debates about what worked in helping to achieve those. It then moves backward in time to explore the origins of elite commitment and state capacity to address (a limited range of) women's concerns, discussing the effects of a series of crises on how elites perceived women and their part in the development process around the time of the country's independence from Pakistan in 1971. It then returns to the challenges of the present - the early years of the SDGs - examining a select number 
of the gender equality targets on which Bangladesh faces an enduring challenge to transform its society and the lives of its female citizens. The analysis of the chapter focuses on exploring whether and to what extent the elite commitment and state capacity necessary to address the SDG challenges are in place, as they were for the MDGs, on which Bangladesh performed relatively well.

\subsection{Gender Equality and Bangladesh's Unexpected Development Success}

\subsubsection{Advances for Bangladeshi Women: From Independence to the MDGs}

Since its liberation from Pakistan in 1971, Bangladesh has made comparatively rapid advances on gender equality, catching up with - and even overtakingregional comparators on health, education, and life expectancy, among other dimensions (World Bank 2007). These gains were from a low base and at a low level of public and private expenditure (Asadullah et al. 2014). Bangladeshi women have benefited from policies and non-state social programmes that prevent hunger, improve livelihoods, extend life expectancies, expand access to basic reproductive and other health services (Chowdhury et al. 2013), get girls into school, and provide social protection for vulnerable women (Hossain 2017). According to the Global Gender Gap Index, which measures the disadvantage women face compared to men in health, education, the economy, and politics, the women of Bangladesh now score higher on some measures of gender equality than their South Asian sisters (see Fig. 21.1), but they lag behind on other important dimensions, notably early marriage (UNICEF [United Nations Children's Fund] 2014). ${ }^{2}$ The Government of Bangladesh increasingly frames gender equality as central to its development successes in export production and human development, and as a goal in its own right (Wazed 2010).

With respect to the third MDG (promote gender equality and empower women), the Government of Bangladesh noted that it had achieved or made rapid progress towards key targets, including:

- successfully eliminating gender disparity in primary and secondary education,

- rapidly reducing gender disparities in tertiary-level enrolments,

- a (slow) rise in the proportion of women wage workers in nonagricultural employment, from 19 per cent in 1991-1992 to 32 per cent in 2013 , and

- women taking a leading role in national politics.

In addition, Bangladesh made rapid progress on a number of other indicators with direct impact on women's lives and well-being, including: 


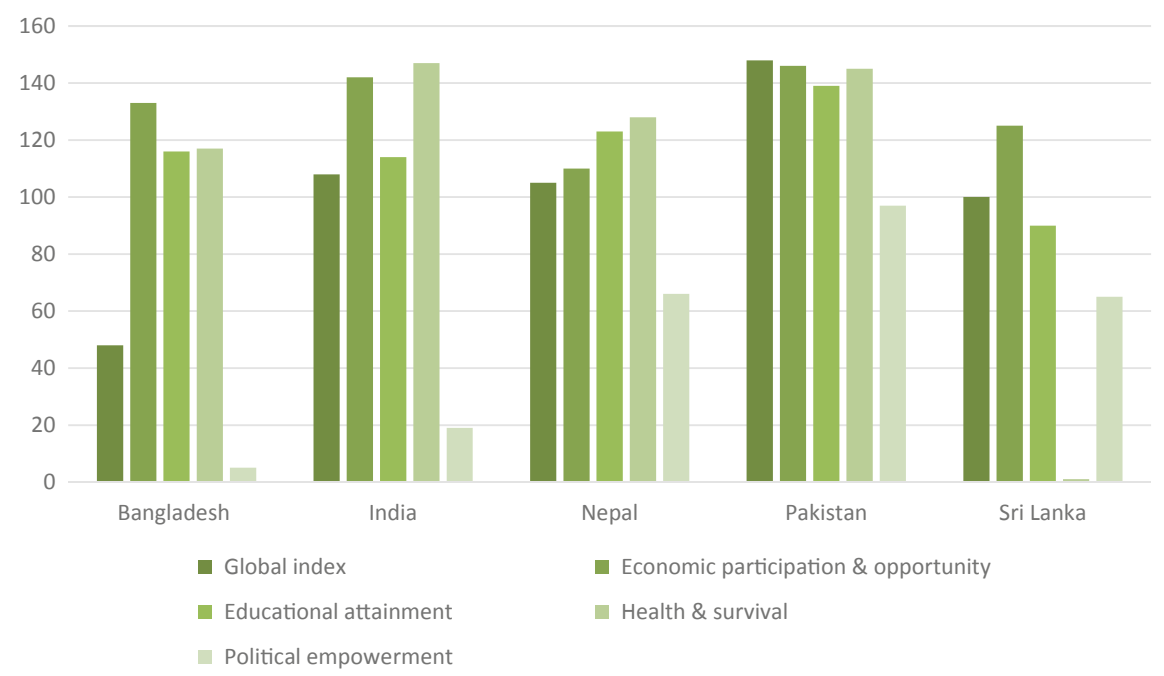

Fig. 21.1 Global Gender Gap Index rankings, South Asia, in 2018 (Note Lower scores indicate lower levels of gender inequality in the particular domain, that is, better scores. Source Author, based on data from the World Economic Forum [2018])

- halving the proportion of the population living in poverty (from 57 per cent in the early 1990s to 25 per cent in 2015) and in extreme poverty (from 25 per cent in 2005 to 13 per cent in 2015);

- rapid reductions in child mortality (under 5 years old-from 151 per thousand live births in 1990 to 36 in 2014) and infant mortality (from 94 per thousand live births in 1990 to 29 in 2015);

- a reduction in maternal mortality rates (from 472 per 100,000 live births in 1991 to 181 in 2015); and

- increases in maternal health care coverage (General Economic Division 2016).

In practical terms, this progress has meant the passage of laws to protect and advance women's rights within marriage, to property, personal safety and security, and political representation; the building of tens of thousands of schools, clinics, and hospitals; the recruitment of hundreds of thousands of health workers, teachers, and administrators - a rising proportion of them women; and the provision of services and social protection to tens of millions of women and their families through cash and food transfers, pensions, micro-credit, work, and income-generation schemes (Begum 2014).

It should be underlined that despite its good progress and general aura of success, Bangladesh did not meet all its MDG commitments on gender equality. In key areas of women's and girls' lives-in particular with respect to violence, poverty, and early marriage-signs of "empowerment" have been less evident than continuing powerlessness and discrimination, reflecting the 
persistence of certain patriarchal norms and practices, despite the significant changes marked by the MDG achievements. Whether incorporation into paid work in the export apparels industry or self-employment through microfinance is "empowering" for women-and if so, what that means for those women in those contexts-has also been the subject of much debate among feminist activists and scholars (Goetz and Gupta 1996; Heath 2014; Heath and Mobarak 2015; Hossain 2012; Kabeer 1999; Kabeer et al. 2018; Karim 2011; Siddiqi 2009). Women face a growing range of new challenges from their greater public civic, political, and labour force participation, including the rise of a new Islamic platform with influence over current politics. At the same time, the SDGs are widely understood to be a more challenging and broader index of development rooted in human rights and the analysis of the structural determinants of poverty, exclusion, and inequality, compared to the MDGs' narrower agenda, which was focused on income poverty and scaling up service provision (Esquivel and Sweetman 2016; Kabeer 2005). Can Bangladesh translate its (modest) successes in the MDGs into a strategy for achieving the SDGs? To understand the prospects for Bangladesh, we first need to understand how it achieved the change it did.

\subsubsection{What Bangladesh Did Right}

How were these comparatively rapid (if uneven) gains for women possible? We can draw on the analysis of Bangladesh's "surprisingly" inclusive development progress more generally by Asadullah et al. (2014) to identify the following determinants of women-oriented or gender-equitable policies in this context. First, Bangladesh had crafted "an inclusive development strategy involving various non-government stakeholders" including religious bodies, aid donors, and non-governmental organisations (NGOs), "which complemented public education and health interventions" (Asadullah et al. 2014, p. 151). Partnerships between state, international aid, and non-state actors helped bring about poverty reduction through services designed specifically to benefit impoverished and marginalised people, and in particular women; they also allowed new approaches to be innovated and tested as well as built on or scaled-up by the government (Hossain 2017).

Second, there were synergies between different forms of social progress so that, for instance, gains in health helped kick-start gains in education at different times. Fertility decline helped improve women's overall status, thereby improving their own health and enabling them to care for fewer children and undertake paid work and civic engagement. Girls' education meant more educated mothers, smaller families, and more investment in children's schooling (Asadullah et al. 2014, p. 151).

A third set of broad factors identified by Asadullah et al. included the very broad category of the geographical and sociocultural context. A small, densely populated landmass and a broadly shared cultural and linguistic heritage helped ensure that policies and programmes could be designed and rolled out 
with comparative ease and at a low cost. In addition, a strong political commitment to inclusive policies, including "[p]utting women in the forefront", featured in these gains (Asadullah et al. 2014, p. 151).

\subsubsection{Ruptures in the Patriarchal Bargain and the Origins of Elite Commitment}

These factors help to explain how Bangladesh transformed aspects of gender relations, thereby changing the relationship between Bangladeshi women and their state over a short space of a couple of generations. But they tell us little about why it overcame such strong gendered cultural and religious norms and traditions in order to do so. We know from political economy research that the broad factors driving inclusive development critically include elite commitment to inclusive policies and state capacity to enable their delivery (Hickey et al. 2015). So what drove elite commitment and state capacity to include women in the project of national development?

One explanation for Bangladesh's rapid progress on aspects of gender equality, despite its unpromising conditions in the early 1970s, was that the natural disasters, conflict, and humanitarian crises of the events surrounding that country's birth "marked a watershed in attempts to deal with women's issues" (Kabeer 1988, p. 110). The province of East Pakistan (soon to become Bangladesh) experienced a devastating cyclone in 1970, which triggered the Liberation War of 1971. It also established a strong political mandate for a nation state that would protect its citizens against such disasters. The war itself saw millions of Bangladeshis killed, displaced, or widowed, as well as the vast destruction of infrastructure and assets. Tens of thousands of women were raped by the Pakistani army and their collaborators, and they found it difficult to be re-integrated into a society in which sexual purity remained critical for gender relations. Not three years after independence, the country experienced a terrible famine in which 1.5 million people died. Women started to come out in their thousands looking for work-challenging norms of purdah (seclusion) - after being forced out by hunger and desperation (Hossain 2018).

These events surrounding the establishment of the new nation came on top of a longer period of decline in the old patriarchal-agrarian bargain, in which rising levels of landlessness and debt had impoverished the rural majority over a generation or more, affecting poor women most directly. In turn, each of these crises politicised the situation of Bangladeshi women in key respects. They meant that the rehabilitation of raped women into society was framed as a matter of national reconstruction and development, creating a precedent for state action and agencies to address women's concerns (D'Costa 2012; D'Costa and Hossain 2010; see in particular, Mookherjee 2008). The famine gave rise to new and pioneering programmes to reach the poorest women, such as Vulnerable Group Development, a food transfer scheme that has been run by the government and the World Food Programme since 
1975. The spectre of famine firmed up a consensus between aid actors and domestic elites around the priority of population control; this meant that finding ways of reaching poor rural women in order to change their reproductive behaviour was crucial. The politics of the crises demanded that the Bangladeshi state develop the "biopower" to protect its citizens, rather than helplessly leaving them to the mercies of the markets or the elements (Hossain 2018). The Bangladesh women's movement, which had a long history of struggling with as well as alongside political elites, played a particularly important role in undertaking research, mobilising support, and framing women's issues as matters of rights and national development (Nazneen 2019; Nazneen and Sultan 2014).

\subsubsection{From Commitment to Capacity}

An elite consensus on the need for development to reach poor women made it possible to build state capacities to work with rural populations and licensed experimental models of governance and service delivery. This included creating space for non-state actors - in a context in which the emerging state lacked human and fiscal resources-as well as the physical outreach and flexibility of NGOs. The extent of the need meant the government of Bangladesh had little option but to seek assistance and build partnerships with NGOs. It is notable that the disasters of the 1970s were also moments when some of Bangladesh's NGOs (BRAC) and micro-credit institutions (Grameen Bank) were founded. Civil society leaders often explain their motivations for their innovative organisations as being due to having witnessed the hardships of the people, in particular of rural poor women, and becoming determined to make changes (Harvard Business School 2014; Yunus and Jolis 1999). Both BRAC and Grameen Bank have notably made women's empowerment and tackling poverty central to their work, and they have developed many innovative models that have been emulated-and criticised-around the world.

After the early 1970s crisis period, Bangladesh experienced a series of brutal political assassinations and coups, after which it embarked on a 15 -year period of military rule that lasted till 1990. During this time, an elite consensus was forged on the need to open up to international aid and move towards economic liberalisation, while also creating space for civil society to operate and ensuring basic social provisioning (in particular, family planning and food security). This included a growing recognition of the centrality of women to development policy as well as the urgent need to reach the mass of female citizens in order to transform the population into a source of national wealth. International aid became a major influence through the introduction of new ideas and financing, often countervailing the push towards more regressive gender policies from Islamic allies in the Middle East and organised religious forces within the country (Hossain 2017). 
At first, there was opposition from within the more conservative and traditionalist sections of society to birth control measures (viewed as unIslamic), girls' schooling, and women attending public meetings. Micro-credit programmes were believed to be associated with raised levels of domestic violence, as some husbands resented women's growing control over household incomes. Yet, there was never an important constituency within the political, economic, or social elite, nor within organised politics or civil society to oppose such measures as scholarships for girls' secondary school, stipends for the mothers of primary schoolchildren, or food or cash transfers for elderly or destitute women. Political parties - even to some extent including those on the moderate religious right-broadly took the same view of the desirability of enabling women to be included in the development process (Nazneen 2009; Nazneen et al. 2011). Across the society, the appraisal of action to reach women was broadly pragmatic after the period of crisis, recognising that poor rural women in particular needed to be able to generate incomes and have the power to control their fertility in order to prevent extreme poverty for both themselves and their children. As the export garments industry took off after the 1980s, business leaders in particular recognised the advantages of policies promoting women's employment beyond the home, as they reaped the profits from an abundant supply of cheap female labour.

The advances in gender equality and women's empowerment of the MDG period were achieved during the country's (mainly) democratic period, in which the two main parties were routinely kicked out of office by the electorate, and in which competition for votes brought a broad range of policies and development performance into the public's political decision-making. For almost 30 years, the country has been ruled by women prime ministers from either party - a feature of Bangladeshi politics that arguably licensed a relatively strong focus on the "soft" social sectors of health, education, and social protection by the government. The women's movement mounted several effective campaigns, in key respects pushing party politics towards greater recognition of women voters. It seems unarguable that democratic competition played an important role in holding the elite consensus together and in creating space for civil society actors, both the women's movement and the service-providing NGOs. Since 2014, however, Bangladeshi politics has been increasingly dominated by a single party. Will that enable the government to sharpen its focus on women's empowerment and gender equality by ignoring claims from the Islamic right for policies to be in line with religion, and directing more resources towards building state capacity for gender equality policies? Or will it mean that the women's movement and popular feeling are suppressed by the increasing domination of the ruling party and the closure of the space for civil and political society? Will NGOs and civil society groups still be able to influence policies in positive ways? These are the key questions for the future achievement of the SDGs. 


\subsection{Next-Generation Challenges: Inclusion, Equality, and "Leaving No One Behind"}

\subsubsection{Intersectionality and Power in the SDGs}

To properly understand the fresh challenge posed by the SDGs, it is necessary to understand where and why Bangladeshi women and girls continue to face significant challenges to their inclusion and equal participation, and in addition, the new challenges they face as a result of their changing social, economic, and political roles. Although all composite indices have their problems, the SDGs offer the promise of a better framework for analysing progress on gender equality and women's empowerment, for a number of reasons. As Esquivel and Sweetman (2016) argue, with 14 indicators addressing legal, political, economic, and social issues, the SDG indicators capture a broader range of dimensions of power at different stages of life and in multiple domains. As they also note, gender cuts across more of the other SDGs, and so it is mainstreamed in a way that was absent from the MDGs. Again, in contrast to the more minimal MDGs (which were set by donors and technocrats), SDG 5 was developed through extensive consultation with the women's movement and civil society activists and feminist scholars. This involvement can be seen in the more structural and intersectional approach taken to the measurement of progress towards women's empowerment in the SDGs, and it entails a recognition of the limitations of a narrow focus on economic empowerment, taking a human rights-based approach with a strong emphasis on equality (Razavi 2016). Such an approach makes possible:

an intersectional analysis of power in which economic, political and social marginalisation based on identities clearly leads to the experience of "being left behind". If the Leave No-One Behind agenda is realised, it may help solve the problem of the limitations of simpler, goal-oriented development in the MDGs, which were able to realise targets because they had less ambitious goals, and therefore left the more difficult development challenges unaddressed ... Leave No-One Behind highlights the fact that the issues facing women in poverty in the global South do not arise from gender inequality only; rather, they are at the intersection of different dimensions of inequality, including race and class. (Esquivel and Sweetman 2016, p. 7)

The SDGs are thus likely to prove to be a harder test of progress on gender equality and women's empowerment, and one which takes into account a broader range of dimensions of power in women's lives, and their intersection with each other. This means, among other things, an inherently more contested model of development cooperation, in which there may be fewer easy wins and more difficult choices and trade-offs. 


\subsubsection{The Problem of Early Marriage: SDGs 3 and 5}

To assess the challenges posed by the SDGs, it helps to examine some of the enduring sources of gender inequality and women's disadvantage in Bangladesh, as well as to understand why they are so difficult to eradicate. The phenomenon of early marriage helps to illustrate the nature of the challenges particularly well.

It is notable that although Bangladesh scored well on the Global Gender Gap Index (see Fig. 21.1), the Gender Inequality Index (GII) of the UN Development Programme's Human Development Report tells a differentand for Bangladesh, a less promising - story. The GII measures the "loss in potential human development due to disparity between female and male achievements in reproductive health, empowerment and economic status". As with the Global Gender Gap Index, it aims to capture the effect of gender inequalities overall in society, but it includes in addition some indicators relating to other SDGs, such as health and education. Table 21.1 summarises the rankings of different South Asian countries on the GII. Ranked above only Pakistan of these major South Asian nations, Bangladesh is at or near the median score across most of the indicators. The exception is the adolescent birth rate (SDG target 3.7), which, at 83.5 per 1000 , is 23 points higher than Nepal (the country with the next-worst adolescent birth rate), more than double that of Pakistan and India, and almost six times higher than in Sri Lanka.

Bangladesh's relatively poor overall performance within South Asia on the GII mainly reflects this extremely high proportion of adolescent births, which, in turn, reflects the very high rate of early marriage for girls in Bangladesh (Kamal et al. 2015; Streatfield et al. 2015). Despite its many gains on gender equality in education and other spheres of life, marriage remains routine for girls below the age of 18 , and Bangladesh has one of the highest rates of early marriage in the world (UNICEF 2014). Both the adolescent birth rate (SDG target 3.7) and SDG target 5.3, which includes an indicator of the "Proportion of women aged 20-24 years who were married or in a union before age 15 and before age 18", aim to capture a core dimension of women's lives-whether they are able to make choices about when they marry and give birth, which is a decision with profound implications for their health and well-being, as well as for their chances of completing further or higher education and of getting paid work.

The stubborn problem of early marriage is a prime example of the nature of the challenge that Bangladesh is likely to face in attempting to attain the SDGs. It reflects, first, a relatively widespread social preference for girls to marry young. In turn, this reflects the absolute priority accorded to female sexual purity in Bengali Muslim culture, and the resulting pressure that parents perceive themselves to be under to ensure girls are married before they can develop independent romantic preferences and/or an undesirable social reputation. It also reflects the high degree of violence and harassment faced by 


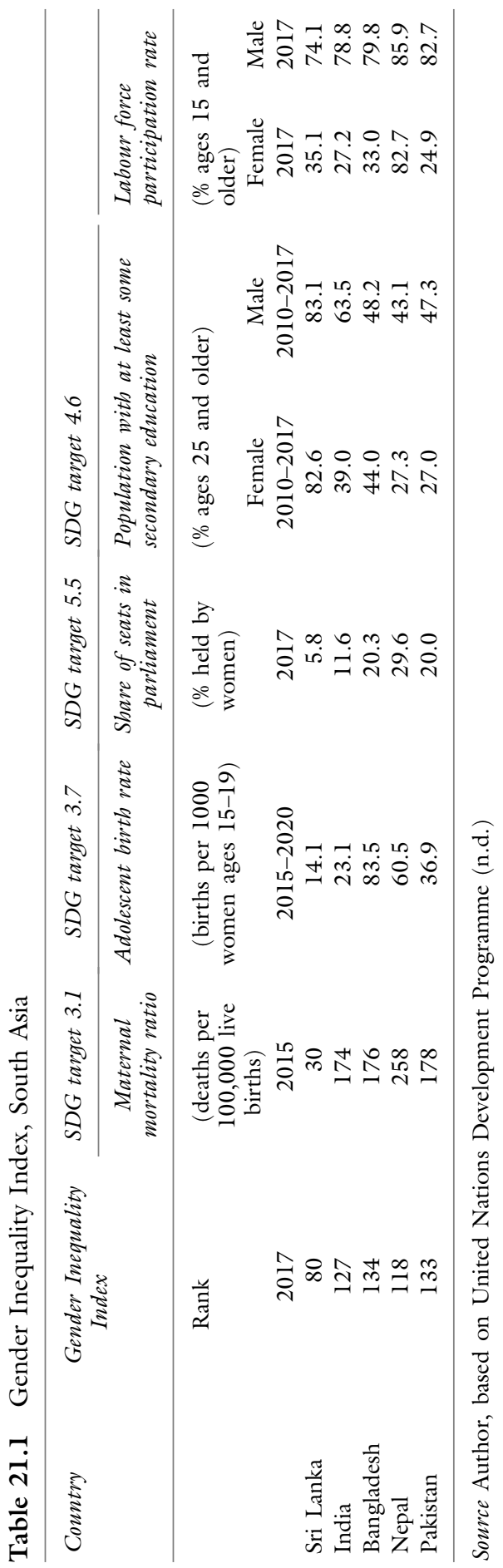


Bangladeshi adolescents (Alam et al. 2010; Nahar et al. 2013) and the fear that harassment will cause the girls to be perceived as sexually active. The high rate of early marriage has also been linked to the prevalence of practices of grooms' families demanding substantial dowries; adolescents and young teenagers tend to be valued more highly than brides over the age of 18, and many parents prefer to marry their daughters off young in order to pay a smaller dowry (Amin and Huq 2008; Schuler et al. 2006).

Second, the persistence of early marriage against a backdrop of policy shifts to promote the educational and employment prospects of women and girls also reflects the extent to which the government has generally succeeded in advancing social agendas when those have been aligned with the popular will. There was a large unmet demand for reproductive health care and family planning, rising demands for universal basic education, and a growing push for access to work opportunities for those women who wanted or needed to earn (Kabeer 2001; Kabeer and Hossain 2004). By contrast, there remains such a strong societal preference for girls to be married young (or to be perceived as younger than 18 at the time of marriage) that many parents appear to prefer to lie about their daughters' ages in order to present them as being younger than they are, even though this means breaking the law (Streatfield et al. 2015). Put another way, the social pressures in favour of early marriage are stronger than the legal and civic pressures to ensure that daughters are over the legal age before they are married. In 2018, under pressure from Islamic clerics, among others, the government actually reduced the legal age at which girls can be married, from 18 to 16 . Although the average age of marriage has been rising over time, it has done so very slowly, increasingly less than a year and a half between 1994 and 2003, a period otherwise known for its rapid progress on gender equality (and in particular for gains in girls' educational enrolment) (Kamal et al. 2015).

Third, the challenge of addressing early marriage has seen government policy not only run up against a widespread societal preference for girls to be married young, but also face relatively concerted and organised opposition from the Islamic right. The surprising volte-face of the government in reducing the age of marriage is believed to reflect the emergence of an influential and radical new Islamist platform (Hefazat), which has replaced the moderate Islamist parties of the past. In part, this group has emerged through virulent struggles against the adoption of the National Women's Development Policy, which had among its aims the equalisation of inheritance laws for men and women (Nazneen 2018). The government has also made concessions to this group regarding madrassab education; this, along with the relaxation of child marriage laws, indicates that, for the first time, development and gender equality policies are likely to face a coherent and organised opposition from the right.

A fourth factor to consider is that whereas the MDG period was characterised by partnerships between the government and aid, civil society, 
NGOs, and community-based organisations, these more inclusive and innovative partnerships have been replaced by an increasingly government-driven agenda. From 1991 to 2014 , the country featured highly competitive multiparty elections, and the media and civil society actors were relatively free to comment on and scrutinise public policy and the implementation of government programmes. In 2014, the present government "won" an uncontested election, which was boycotted by the opposition, who deemed it illegitimate. It went on to politicise the administration and restrict or co-opt civil society actors using a mixture of law, criminalisation, administrative measures, and stigmatisation, as well as outright intimidation and violence (Hassan and Nazneen 2017; Human Rights Watch 2017). The 2018 election is widely understood to have been thoroughly rigged to secure the position of the incumbent party. Civil society actors and the media have been cowed and threatened, and although they have not been entirely silenced or stopped, they are now forced to select their struggles carefully, at the risk of being deregistered or otherwise stopped. Women's movement actors are among those who have been silenced or co-opted.

Taken together, these factors signal that the conditions that enabled earlier-and in some respects, less radical-policy changes are no longer in place, or at least not for the stubborn problem of child marriage. The overall policy environment since 2014 has not been one of respect for human rights, although it has given an even stronger emphasis to service delivery and economic development than in the past. Yet, as the SDGs themselves indicate, women's empowerment and gender equality are not individual measures such as girls' enrolment in school or participation in non-agricultural wage work.

The critical question for Bangladesh as it strategises for achieving the SDGs is whether a strong political elite commitment to deliver services can overcome these features of the social and political environment that were absent during the MDG period. With respect to early marriage, these include a misalignment between societal and state goals; a lack of clear elite consensus over its importance; the presence of an increasingly organised opposition to gender equality policies, and in particular to stopping adult men from marrying girl children; and the increasingly state-dominated development process, which reduces the prospects for innovation through multi-stakeholder partnerships, accountability for achieving the SDGs, and in particular ensuring that no one is "left behind by development". 


\subsubsection{Women Workers' Rights: SDGs 1, 8, and 16}

The past 30 years have seen dramatic changes in women's lives in Bangladesh. Among these is mass women's employment in export-sector garments production, which has, over the decades, brought millions of Bangladeshi women into formal industrial relations. At present, around 2 to 3 million women work in the industry, which accounts for 80 per cent of exports.

Incorporation into global value chains has undoubtedly been empowering for Bangladeshi women faced with the options of even lower-paid rural subsistence occupations or the rigours and uncertainties of family farming or domestic service (Hossain 2012; Kabeer and Mahmud 2004; Kabeer et al. 2018). Yet, wages have remained low, while living costs have risen, notably over the past decade. Evidence indicates that, even with two adults working, a household reliant on garment workers' wages would live below the poverty line (Moazzem and Arfanuzzaman 2018).

The new opportunities of ready-made garment employment have also seen women incorporated into global value chains on adverse terms, exposing them to new sources of discrimination and structural violence. The disastrous Rana Plaza factory collapse of 2013 - the worst industrial disaster in the history of the global garments trade-graphically illustrated the effects of the lack of power of garment workers to resist pressures to turn up for work in unsafe factories in order to perform tough, but underpaid, labour. Since the calamity of 2013, which threatened the very existence of this overwhelmingly important industry in Bangladesh, garment workers have taken increasingly effective, if dangerous, collective action to demand safety at work and higher wages (Ashraf and Prentice 2019; Siddiqi 2015).

So although women have won some degree of economic empowerment through their precarious factory labour, this has chiefly been exercised in relation to the home and personal relationships. However, women workers remain deeply disempowered in relation to factory owners, the state, and the international buyers that source in Bangladesh. It has become increasingly evident that their empowerment and the achievement of decent work depend on their right to unionise and claim their rights. The Bangladeshi elite - and in particular the business elite-are not behind unionisation, in the belief that it would push wages infeasibly high and/or destroy the industry's competitive advantage. Under pressure from international trade regimes and international human rights institutions, the government is seeking ways of improving industrial relations without antagonising their important supporters in business.

Among the SDGs, the targets that are most at risk are SDG target 8.5 ("By 2030, achieve full and productive employment and decent work for all women and men, including for young people and persons with disabilities, and equal pay for work of equal value") and SDG target 8.8 ("Protect labour rights and promote safe and secure working environments for all workers, 
including migrant workers, in particular women migrants, and those in precarious employment"). Again, the SDGs mainstream gender across the set; with respect to Bangladesh's garment workers, it is clear that their disempowerment is by no means purely a result of their gender, but of how their gender intersects with class as well as political and economic power. The achievement of SDG 16 (peace, justice, and strong institutions) also speaks to these challenges, as they highlight the problem of violence and intimidation against trade union and labour activists, and its connections with the achievement of decent work, gender equality, and women's empowerment.

Bangladesh has been a (somewhat reluctant) host to a range of transnational multi-stakeholder initiatives to improve working conditions in garments factories ever since the Rana Plaza disaster (Donaghey and Reinecke 2018; Evans 2014; Khan and Wichterich 2015). In key respects, this has created an environment for experimentation with global governance that resembles the experimentation of earlier non-state innovations with service delivery and reaching women. The Bangladeshi labour movement remains weak and fragmented, however, and has been historically insufficiently attentive to women workers' concerns (Rahman and Langford 2012; Siddiqi 2017). Despite changes to the labour law, in practice, labour activism is dangerous and often violently suppressed. Women (and men) garment workers in Bangladesh are increasingly taking collective action nonetheless, and they are at times winning concessions over the minimum wage or other demands. Their struggles, while evidence of the growing desire to organise, are also evidence of the very high costs that many continue to pay to achieve their basic rights.

\subsection{CONCLUSIONS}

This chapter has reflected on Bangladesh's surprisingly rapid-if uneven and incomplete-progress on gender equality and women's empowerment. It explored both the scope and nature of that progress and how it came about. It also draws attention to the reasons why elites came to be committed to public action on some aspects of gender equality and women's empowerment (notably, social protection and income generation for poverty reduction, fertility control, and mass education), and therefore to building state-and indeed non-state-capacity to do so. Under conditions of multi-party competition and a flourishing civil society sector, Bangladesh made good progress on some of the MDGs-better than could have been expected because of its poverty, traditional patriarchal norms and institutions, and the predominantly Islamic faith of the population. The chapter notes the importance of ruptures in the old patterns and assumptions about gender relations around the country's tumultuous independent period. In particular, it notes recognition by elites that societal institutions such as marriage, the family, and the community were failing to protect Bangladeshi women against disasters, conflicts, and the grinding problems of poverty that so many millions faced. In a country without substantial natural resources, in which the main wealth 
was its people, addressing women's concerns became a matter of addressing the country's national development agenda and building a more productive-healthier, better nourished, better educated, and socialised-workforce. Governments developed inclusive partnerships with aid actors, civil society groups, and NGOs, and the women's movement played a critical role both in advancing an understanding of the instrumental importance of women's empowerment for national development as a whole and in sharing norms about women's rights and strategies for realising them.

What does Bangladesh's positive performance on the MDGs tell us about the prospects for the SDGs? The SDGs are more demanding, embedding an understanding of women's disadvantage not only concerning their gender, but also of how gender intersects with class, ethnicity and religion, and geography, among other factors. The SDGs draw attention to a broader range of factors affecting power in women's lives than the MDGs - and with greater attention being given to women and girls across their entire lives. The chapter analyses two enduring challenges facing women in Bangladesh in the light of the SDG emphasis on inclusion, equality, and "leaving no one behind" by development: early marriage and women workers’ rights in global value chains. Each of these challenges is analysed in the light of what we have learnt about how Bangladesh succeeded (to the extent it did) in the MDGs. Several points stand out.

First, the "first generation" gains of girls' education and family planning services aligned closely with societal interests and concerns. By contrast, early marriage persists because of a broad societal preference (within highly constrained and gender-unequal conditions) for girls to be married young. The garments sector as a whole has been built on the low wages and presumed docility of women workers, and the interests in keeping it so are widespread and powerful.

The second point, which is related to the first, is that there is no elite consensus on these enduring and new challenges. Religious elites hold fast to their privileges, including having sex with girl children, even while the political and social elite decry the closely associated practices of dowry and child marriage, which are both fundamental to the violence faced by women and girls. State, political, civil society, and business elites are divided on the issue of unionisation in the industry, and so more powerful voices prevail. Issues of minimum wages and working conditions are proving to be topics of great contestation, in which cooperation or collaboration has to date proved elusive.

Third, whereas neither fertility control nor education or even micro-credit schemes have elicited much organised resistance from politically powerful groups, the rise of a new and more militant Islamic platform has successfully foisted a more Islamist agenda on the erstwhile secular ruling government. It is within this context that the law has been changed to reduce the legal age at which girls can marry. With respect to garments, women (and men) workers are prevented from realising their rights to form trade unions by a powerful 
business elite with strong and multiple connections to political power at both the local and national levels.

Fourth, political and civic spaces have been sharply curtailed just as the SDGs are being launched. The development process is increasingly being dominated by the state-party system of government under a party that has ruled (as of 2019) for a full decade. In theory, a more powerful government could build stronger capacity to implement important gender equality policies against the will of powerful religious or business actors. Yet, it may equally push out and silence the voices of the women's movement, NGOs, and civil society groups with knowledge, capacity, or access. The country's successes with development cooperation and effective aid during the MDG period may not easily be replicated amid the more widespread and polarised contention surrounding issues such as girl child marriage and minimum wages. Official development assistance is, overall, considerably less important to the policies Bangladesh is now designing and implementing. These are critical considerations for Bangladesh as it graduates from LDC status and takes its position as a middle-income country in its 50 year. The SDGs will provide a critical test for the "Bangladeshi model" of development.

\section{Notes}

1. See, for instance, Asadullah et al. (2014), Chowdhury et al. (2013), Hossain (2017), and Mahmud et al. (2008).

2. The UN Gender Inequality Index for 2017 ranked Bangladesh 134 out of 188 countries, compared to Sri Lanka at 80, Nepal at 118, India at 127, and Pakistan at 133 , just above Bangladesh. This ranking, apparently at odds with other composite indices, appears to relate to the very high proportion of adolescent mothers in Bangladesh (between one-third and two-thirds higher than elsewhere in South Asia), which is one of five indicators measured. GII data is from UNDP (n.d.).

\section{REFERENCES}

Abed, F. H. (2013). Bangladesh's health revolution. The Lancet, 382(9910), 20482049.

Alam, N., Roy, S. K., \& Ahmed, T. (2010). Sexually harassing behavior against adolescent girls in rural Bangladesh: Implications for achieving Millennium Development Goals. Journal of Interpersonal Violence, 25(3), 443-456.

Amin, S., \& Huq, L. (2008). Marriage considerations in sending girls to school in Bangladesh: Some qualitative evidence. New York, NY: Population Council.

Asadullah, M. N., Savoia, A., \& Mahmud, W. (2014). Paths to development: Is there a Bangladesh surprise? World Development, 62, 138-154.

Ashraf, H., \& Prentice, R. (2019). Beyond factory safety: Labor unions, militant protest, and the accelerated ambitions of Bangladesh's export garment industry. Dialectical Anthropology, 43(1), 93-107. 
Begum, F. S. (2014). Gender equality and women's empowerment: Suggested strategies for the 7th five year plan. Dhaka: General Economics Division, Bangladesh Planning Commission, Government of the People's Republic of Bangladesh.

Chowdhury, A. M. R., Bhuiya, A., Chowdhury, M. E., Rasheed, S., Hussain, Z., \& Chen, L. C. (2013). The Bangladesh paradox: Exceptional health achievement despite economic poverty. The Lancet, 382(9906), 1734-1745.

D'Costa, B. (2012). Women, war, and the making of Bangladesh: Remembering 1971. Journal of Genocide Research, 14(1), 110-114.

D'Costa, B., \& Hossain, S. (2010). Redress for sexual violence before the International Crimes Tribunal in Bangladesh: Lessons from history, and hopes for the future. Criminal Law Forum, 21(2), 331-359.

Donaghey, J., \& Reinecke, J. (2018). When industrial democracy meets corporate social responsibility-A comparison of the Bangladesh accord and alliance as responses to the Rana Plaza Disaster. British Journal of Industrial Relations, 56(1), $14-42$.

Esquivel, V., \& Sweetman, C. (2016). Gender and the Sustainable Development Goals. Gender \& Development, 24(1), 1-8.

Evans, B. A. (2014). Accord on fire and building safety in Bangladesh: An international response to Bangladesh labor conditions notes \& comments. North Carolina Journal of International Law and Commercial Regulation, 40(2), [i]-628.

General Economic Division. (2016). Millennium Development Goals (MDGs): Endperiod stocktaking and final evaluation (2000-2015). Dhaka: General Economics Division, Bangladesh Planning Commission, Government of the People's Republic of Bangladesh.

Goetz, A. M., \& Gupta, R. S. (1996). Who takes the credit? Gender, power, and control over loan use in rural credit programs in Bangladesh. World Development, $24(1), 45-63$.

Harvard Business School. (2014, April 24). Interview with Fazle Abed, interviewed by Tarun Khanna. http://www.hbs.edu/businesshistory/Documents/emerging-mar kets-transcripts/Abed_Fazle_Web\%20Copy.pdf.

Hassan, M., \& Nazneen, S. (2017). Violence and the breakdown of the political settlement: An uncertain future for Bangladesh? Conflict, Security \& Development, $17(3), 205-223$.

Heath, R. (2014). Women's access to labor market opportunities, control of household resources, and domestic violence: Evidence from Bangladesh. World Development, 57, 32-46.

Heath, R., \& Mobarak, A. M. (2015). Manufacturing growth and the lives of Bangladeshi women. Journal of Development Economics, 115, 1-15.

Hickey, S., Sen, K., \& Bukenya, B. (2015). Exploring the politics of inclusive development: Towards a new conceptual approach. In S. Hickey, K. Sen, \& B. Bukenya (Eds.), The politics of inclusive development: Interrogating the evidence (pp. 3-34). Oxford: Oxford University Press.

Hossain, N. (2005). Elite perceptions of poverty in Bangladesh. Dhaka: University Press Limited.

Hossain, N. (2012). Exports, equity, and empowerment: The effects of readymade garments manufacturing employment on gender equality in Bangladesh. Washington, DC: World Bank. 
Hossain, N. (2017). The aid lab: Understanding Bangladesh's unexpected success. Oxford: Oxford University Press.

Hossain, N. (2018). Post-conflict ruptures and the space for women's empowerment in Bangladesh. Women's Studies International Forum, 68, 104-112.

Human Rights Watch. (2017). Bangladesh: Events of 2016. https://www.hrw.org/ world-report/2017/country-chapters/bangladesh.

Kabeer, N. (1988). Subordination and struggle: Women in Bangladesh. New Left Review, 168, 95-121.

Kabeer, N. (1999). Resources, agency, achievements: Reflections on the measurement of women's empowerment. Development and Change, 30(3), 435-464.

Kabeer, N. (2001). Ideas, economics and "the sociology of supply": Explanations for fertility decline in Bangladesh. The Journal of Development Studies, 38(1), 29-70.

Kabeer, N. (2005). Gender equality and women's empowerment: A critical analysis of the third Millennium Development Goal 1. Gender \& Development, 13(1), 13-24.

Kabeer, N., \& Hossain, N. (2004). Achieving universal education and eliminating gender disparity in Bangladesh. Economic and Political Weekly, 39(36), 4093-4095, 4097-4100.

Kabeer, N., \& Mahmud, S. (2004). Globalization, gender and poverty: Bangladeshi women workers in export and local markets. Journal of International Development, 16(1), 93-109.

Kabeer, N., Mahmud, S., \& Tasneem, S. (2018). The contested relationship between paid work and women's empowerment: Empirical analysis from Bangladesh. The European Journal of Development Research, 30(2), 235-251.

Kamal, S. M. M., Hassan, C. H., Alam, G. M., \& Ying, Y. (2015). Child marriage in Bangladesh: Trends and determinants. Journal of Biosocial Science, 47(1), 120-139.

Kandiyoti, D. (1988). Bargaining with patriarchy. Gender \& Society, 2(3), 274-290.

Karim, L. (2011). Microfinance and its discontents: Women in debt in Bangladesh. London and Minneapolis, MN: University of Minnesota Press.

Khan, M. R. I., \& Wichterich, C. (2015). Safety and labour conditions: The accord and the national tripartite plan of action for the garment industry of Bangladesh (Global Labour University Working Paper No. 38). Geneva: International Labour Organization.

Khatun, F. (2018). Can Bangladesh do without foreign aid? https://cpd.org.bd/wpcontent/uploads/2018/11/Can-Bangladesh-do-without-Foreign-Aid.pdf.

Mahmud, W., Ahmed, S., \& Mahajan, S. (2008). Economic reforms, growth, and governance: The political economy aspects of Bangladesh's development surprise (Working Paper No. 22). Washington, DC: World Bank.

Mason, A., \& King, E. (2001). Engendering development through gender equality in rights, resources, and voice. Washington, DC: World Bank.

Moazzem, K. G., \& Arfanuzzaman, Md. (2018). Addressing the livelihood challenges of RMG workers: Exploring scope within the structure of minimum wages and beyond (CPD Working Paper 122). Dhaka: Centre for Policy Dialogue.

Mookherjee, N. (2008). Gendered embodiments: Mapping the body-politic of the raped woman and the nation in Bangladesh. Feminist Review, 88, 36-53.

Nahar, P., van Reeuwijk, M., \& Reis, R. (2013). Contextualising sexual harassment of adolescent girls in Bangladesh. Reproductive Health Matters, 21(41), 78-86.

Nazneen, S. (2009). Something is better than nothing: Political party discourses on women's empowerment in Bangladesh. South Asian Journal, 24, 44-52. 
Nazneen, S. (2018). Binary framings, Islam and struggle for women's empowerment in Bangladesh. Feminist Dissent, 3, 194-230.

Nazneen, S. (2019). Building strategic relationships with the political elites. In S. Nazneen, S. Hickey, \& E. Sifaki (Eds.), Negotiating gender equity in the global South: The politics of domestic violence policy (pp. 129-151). London: Routledge.

Nazneen, S., Hossain, N., \& Sultan, M. (2011). National discourses on women's empowerment in Bangladesh: Continuities and change. http://www.ids.ac.uk/files/ dmfile/Wp368.pdf.

Nazneen, S., \& Sultan, M. (2010). Reciprocity, distancing, and opportunistic overtures: Women's organisations negotiating legitimacy and space in Bangladesh. IDS Bulletin, 41(2), 70-78.

Nazneen, S., \& Sultan, M. (Eds.). (2014). Voicing demands: Feminist activism in transitional contexts. London: Zed Books.

Rahman, Z., \& Langford, T. (2012). Why labour unions have failed Bangladesh's garment workers. In S. Mosoetsa (Ed.), Labour in the global South: Challenges and alternatives for workers (pp. 87-106). Geneva: International Labour Organization.

Razavi, S. (2016). The 2030 Agenda: Challenges of implementation to attain gender equality and women's rights. Gender of Development, 24(1), 25-41.

Schuler, S. R., Bates, L. M., Islam, F., \& Islam, Md. K. (2006). The timing of marriage and childbearing among rural families in Bangladesh: Choosing between competing risks. Social Science and Medicine, 62(11), 2826-2837.

Siddiqi, D. M. (2009). Do Bangladeshi factory workers need saving? Sisterhood in the post-sweatshop era. Feminist Review, 91, 154-174.

Siddiqi, D. M. (2015). Starving for justice: Bangladeshi garment workers in a "PostRana Plaza" world. International Labor and Working-Class History, 87, 165-173.

Siddiqi, D. M. (2017). Before Rana Plaza: A history of labour organizing in Bangladesh's garments industry. In V. Crinis \& A. Vickers (Eds.), Labour in the clothing industry in the Asia Pacific (pp. 60-79). Abingdon and New York, NY: Routledge.

Streatfield, P. K., Kamal, N., Ahsan, K. Z., \& Nahar, Q. (2015). Early marriage in Bangladesh. Asian Population Studies, 11(1), 94-110.

UNDP (United Nations Development Programme). (n.d.). Gender Inequality Index. http://hdr.undp.org/en/composite/GII.

UNICEF (United Nations Children's Fund). (2014). Ending child marriage: Progress and prospects. New York, NY: Author.

Wazed, P. M. S. H. (2010). High Level Plenary Meeting-Millennium Development Goals (MDGs): Statement by Her Excellency Sheikh Hasina, Prime Minister, Government of the People's Republic of Bangladesh. https://pmo.portal.gov.bd/sites/def ault/files/files/pmo.portal.gov.bd/pm_speech/37621cb8_5c27_4133_9014_78fe 6lc8f25e/High\%20Level\%20Plenary\%20Meeting_MDGs_20_220910.pdf.

World Bank. (2007). Whispers to voices: Gender and social transformation in Bangladesh. Dhaka: Author.

World Economic Forum. (2018). Global gender gap report 2018. https://www.wef orum.org/reports/the-global-gender-gap-report-2018.

Yunus, M., \& Jolis, A. (1999). Banker to the poor: The autobiography of Mubammad Yunus, founder of the Grameen Bank. London: Aurum Press. 
Open Access This chapter is licensed under the terms of the Creative Commons Attribution 4.0 International License (http://creativecommons.org/licenses/by/4.0/), which permits use, sharing, adaptation, distribution and reproduction in any medium or format, as long as you give appropriate credit to the original author(s) and the source, provide a link to the Creative Commons license and indicate if changes were made.

The images or other third party material in this chapter are included in the chapter's Creative Commons license, unless indicated otherwise in a credit line to the material. If material is not included in the chapter's Creative Commons license and your intended use is not permitted by statutory regulation or exceeds the permitted use, you will need to obtain permission directly from the copyright holder. 